\title{
Transdisciplinary Pedagogy for Science and Journalism Majors Linking Water Resource Information to Communities
}

\author{
Lee J. Floreaํㅗ Adam J. Kuban² \\ ${ }^{1}$ Indiana Geological and Water Survey, Indiana University, 1001 E. 10th St., Bloomington, IN, USA, 47405 \\ ${ }^{2}$ Department of Journalism, Ball State University. 2000 W. University Ave., Muncie, IN, USA, 47306 \\ E-mail: Iflorea@indiana.edu \\ Received 06/05/2020 \\ Accepted for publication 11/26/2020 \\ Published 04/2021 \\ Suggested citation: Florea, L.J., Kuban, A. J., 2021, Transdisciplinary Pedagogy for Science and Journalism Majors Linking Wa- \\ ter Resource Information to Communities: Indiana Geological and Water Survey, Indiana Journal of Earth Sciences, v. 3. DOI \\ 10.14434/ijes.v3i1.30782. \\ Editor's Note: This manuscript complements, but does not chronologically follow, "Crystal Clear" by Kuban and others (2019), a pa- \\ per that appeared in IJES v. 2. In that paper, concerns about arsenic in Indiana's groundwater were explored through the lens of a stu- \\ dent-produced documentary at Ball State University in Muncie, Indiana. This article is a quantitative exploration of student learning \\ during the development of the Water Quality Indiana program at Ball State that led to those later student-led studies.
}

\begin{abstract}
:
Water Quality Indiana is a learning platform that leverages collaborations, community partnerships, and active mentorship of transdisciplinary student cohorts. Since 2013, this platform has engaged teams of science, technology, engineering, and mathematics (STEM) and communication and media students to investigate water quality in east central Indiana (since expanded to other domestic and international locations) in an experiential problem-based learning environment. For community partners, Water Quality Indiana provides scientific data, analysis, and multimedia deliverables about water quality, and it has a successful record of finding solutions to real-world problems. From the point of view of faculty, project deliverables enhance several aspects of a faculty portfolio. For student participants, the goal is to increase metacognition, civic engagement, and confidence in processes associated with STEM and media studies, and, therefore, the transdisciplinary skills required in an increasingly competitive workforce.

Assessing learning artifacts (e.g., assignment, quizzes, or other evaluative metrics) reveals a cognitive dissonance between metacognition and accuracy in declarative knowledge related to topics in water quality-student scores did not increase in posttest data despite an increased confidence in selected answers. In contrast, pretest and posttest results, synthesis reports, and focus group data suggest that confidence in procedural knowledge in both water quality and media production significantly increased by the end of the course. Students cited time constraints imposed by academic calendars and project deadlines as a limitation of the learning environment. Course data reveal differences based on academic background and gender: 1) media studies majors became more confident in their multimedia skills, while STEM majors became less confident; 2) note-taking style and detail is more organized and meticulous for female and STEM students compared to male and media studies counterparts.
\end{abstract}




\section{PROJECT INTRODUCTION}

Education either functions as an instrument that is used to facilitate the integration of the younger generation into the logic of the present system and bring about conformity to it, or it becomes the practice of freedom, the means by which men and women deal critically and creatively with reality and discover how to participate in the transformation of their world (Freire, 2000).

Performance-based funding models are increasingly applied by state legislatures to secondary and postsecondary education. In Indiana, performance criteria for universities include completed credit hours, on-time graduation, and degrees awarded to at-risk students (first generation, minority, etc.) and in high-impact (STEM) areas. Thus, educators are increasingly pressured to teach to a test and to pass students to prevent negative impacts to their institution and careers; consequently, pedagogical assessment is measured in numbers rather than personal experiences. Paradoxically, industry professionals value an entry-level employee's ability to solve problems and be resourceful in novel situations (Baldoni, 2010; McAdams, 2012; Marr, 2019; Wilkie, 2019; NACE, 2020). Students also desire practical, engaged pedagogy (Breiburd, 2017; Cavanagh, 2020). "Most young people...want to know exactly why they are doing something and [that] they are having a personal impact" (Twenge, 2013, p. 68). Postsecondary institutions often lack this pedagogy, for example, in the intersection of geoscience education and journalism. "Rarely do educators ask...how schools can prepare students to be informed citizens, nurture a civic imagination or teach them to be self-reflective about public issues and the world in which they live" (Giroux, 2010, parag. 3).

Scientists understand complex processes but often lack the experience to communicate those ideas to a lay audience (Reed and Walker, 2002); Bhattacharya (2012) noted that scientists commonly misunderstand the standard structure of news and the reason for word limits (lyengar and Massey, 2018). In contrast, journalists may struggle to comprehend advanced scientific terminology; focus groups interviewed by Reed and Walker (2002) revealed misconceptions and tensions, leading to recommendations for basic media training for scientists.

\section{Experiential Project-Based Learning}

Educators and administrators have criticized the "narrow regime of teaching" and challenged educators to prepare students for a lifetime of ill-defined problems. Problem-based learning (PBL) is "a comprehensive approach to classroom teaching and learning that is designed to engage students in investigation of authentic problems" Blumenfeld (1991, p. 369). Barrows and Tamblyn (1976) identified PBL as both a curriculum and a process in which students remain responsible for both questions and solutions to problems.

Case studies reveal that both students and teachers respond favorably to PBL-oriented courses (Tseng et al., 2013; Finkle and Torp, 1997; Barrows and Tamblyn, 1976; Rosenfeld and Ben-Hur, 2001). For example, Duch (1995) noted "PBL...challenges students to 'learn to learn', working cooperatively in groups to seek solutions to world problems." Blumenfeld (1991) identified two advantages of PBL: It encourages interdisciplinary collaboration, and it is adaptable to many situations and different learning styles. Giroux (2010, parag. 7) argued that instruction should "provide the knowledge, skills and social relations that enable students to expand the possibilities of what it means to be critical citizens."

Experiential learning theory defines learning as "the process whereby knowledge is created...from the combination of grasping and transforming experience" (Kolb and Boyatzis, 1984, p. 41). Giroux (2010, parag. 9) might argue that students must be provided this opportunity, as it allows them "to come to terms with their own power as critically engaged citizens." Yet, Giroux (2010) notes a clear absence of this brand of pedagogy in the academy, while other scholars have offered pedagogical guidance for its inclusion (Mitchell, 2008, Beckman and Wood, 2016).

Aspiring journalists need experiences through which they can learn science-the process of experimentation as well as how to report findings-and not just read about how to do it, take a test, or complete a low-stakes exercise. "The old model of two tests-a midterm and a finalis not effective for this group, or, as some may argue, is not effective for any group of learners. Generation Me's self-confidence and easy access to information leads them to prefer interactive learning" (Twenge, 2013, p. 67-68). Twenge (2013) uses "Generation Me" as a broad label for college students at the time of that publication.

\section{The Water Quality Indiana Program}

The design and implementation of Water Quality Indiana (WQI) at Ball State University (BSU) is grounded by tenets of problem-based learning (PBL) and experiential learning course design. The WQI program's transdisciplinary experiential format leverages ongoing and well-documented studies of water quality within rivers of east central Indiana to provide PBL opportunities for geoscience education and to connect student cohorts to community partners, stakeholders, and the larger public in an effort to enhance watershed management plans and restoration programs. Project deliverables are available for public access at the Water Quality Indiana website (www.waterqualityIN.com). 
Table 1. Learning outcomes and descriptions for WQI

- Master transdisciplinary skills. Students demonstrate greater knowledge, skill, and confidence in water quality methods and multimedia production;

- Synthesize information. Students collect data, recognize trends, and generate predictions within the context of rivers and watersheds;

- Foster effective communication. Students design visual representations of scientific results from samples analysis, articulate importance, and publicly share project outcomes;

- Create sustainable solutions. Students develop meaningful solutions to real-world problems of water quality;

- Bridging of scale. Students understand connections between water quality concerns important to local communities and national implications of those events;

- Develop a holistic outlook. Students understand concepts of water quality science from several viewpoints and backgrounds.

- Identify professional opportunities. Students explore study/career paths and develop marketable skills in the geosciences and multimedia.

Some concerns about PBL and experiential programs include the up-front investment to implement the courses and the comparative value versus a more traditional classroom approach. The challenge to measuring program impact is that, despite identical setups between iterations, cohorts are essentially case studies with small populations, so results are hard to compare or generalize to a larger population. Still, in an era where students and stakeholders demand more practical applicability in higher education, it seemed prudent to assess the WQI program using quantitative and qualitative measures and to compare the results to learning outcomes aligned with workforce skills important to young professionals (Table 1).

This paper reports on program assessment of student cohorts from 2013 and 2014 ${ }^{1}$. These data provide some insight of how WQI is achieving the learning outcomes. The discussion will focus on two primary questions illustrated through the accumulated data: Does WQI and experiential PBL foster learning and confidence? What do WQI students value?

\section{WATER QUALITY IN EAST-CENTRAL INDIANA}

Large-scale deforestation and dewatering following the Swamp Land Act of 1850 resulted in increased land for agriculture with concurrent long-term degradation in topsoil quantity and quality in the midwestern United States, including east central Indiana (fig. 1). In the Mississinewa River watershed, a tributary of the Wabash River, more than 88 percent of land use is agricultural (IDEM, 2001). In the headwaters of the adjacent White River watershed, most tributary streams include ditches and tile drains in fields to remove excess soil water.

Nutrients. Agricultural runoff from ditches and tile drains is a "non-point" contamination source. Soil nutrients and

1 WQI classes are not scheduled annually. Since the 2014 class, two more classes were offered (in 2016 and in 2019). In these latter iterations, WQI expanded its geographic reach to include domestic and international water quality issues. sediments can be challenging to identify and manage, but they are a key element of downstream water quality (Voelker and Renn, 2000). Headwater streams, with limited protections for riparian zones, are a central focus for nitrogen and phosphorous mobilization. More recently, attention has focused on point sources of contamination, including the aging infrastructure of combined sewer overflows that convey untreated municipal waste during periods of high discharge and the management of confined animal feeding operations with associated lagoons or spray fields for manure waste. The watersheds of east central Indiana rank among the highest in the nation for nutrient exports (Robertson and others, 2009).

Sediments. Excess sedimentation changes a river's channel, resulting in flooding and loss of critical habitat for fish and mussels. In the White River, Crawford and others (1996) concluded that fish communities "have been affected by...erosion resulting from conversion of forest land to cropland [that] led to siltation of streambeds..." (p. 1). Properly managed riparian zones are vital, because sediment load largely derives from stream bank erosion rather than field runoff (Fox and others, 2006, 2007).

Debris. The Indiana General Assembly in 2009 noted: "erosion has been a problem along the Mississinewa River in Randolph County, washing away the banks. For years, trees have toppled into the river, blocking the river's flow and forcing the Mississinewa to change course. These course changes have led to flooded farm fields, yards and other property" (IDEM, 2001). These logjams on the Mississinewa River likely resulted from channel dredging and straightening in the 1950s from the Ohio state line to the town of Ridgeville, Indiana (fig. 1). Increased river gradient culminated in an increase in peak discharge during storms, elevated bank stress, and erosion of the riparian zone. Conversely, the stream reach from Ridgeville to Albany is unaltered, trapping the upstream debris as logjams, leading to pooled backwaters, sediment deposition, eutrophication, and the 


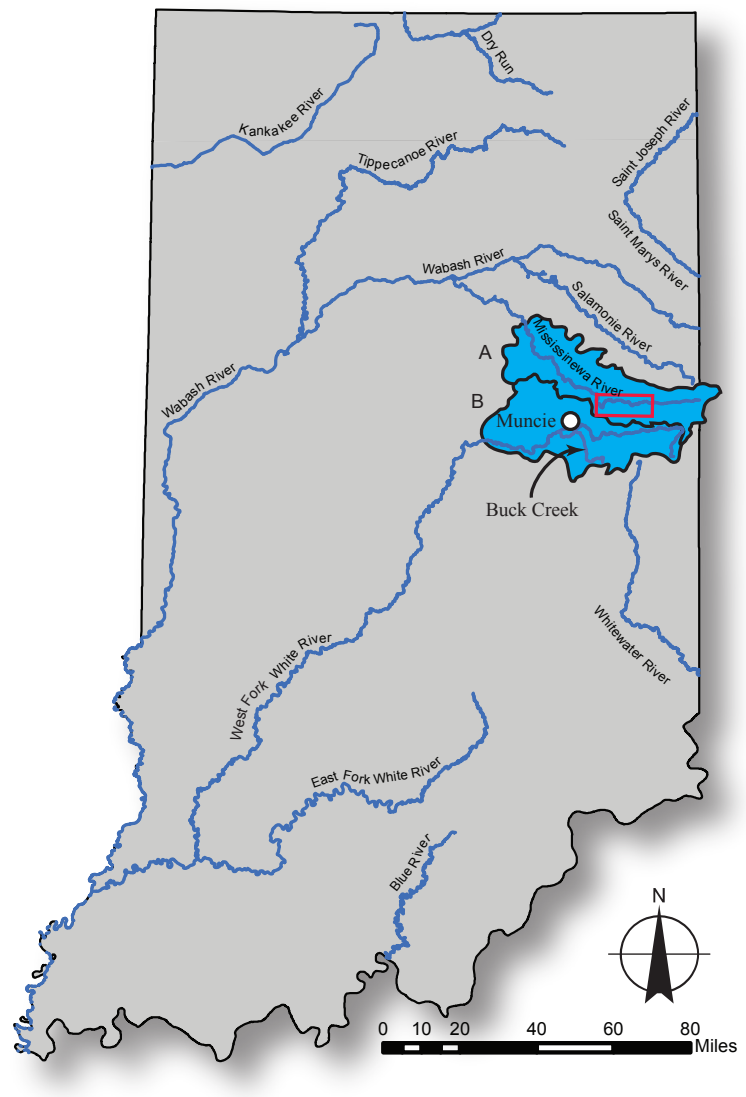

Figure 1. Map of Indiana showing principal rivers and the city of Muncie. Blue areas denote the watersheds of the Upper Mississinnewa River (A) and the Upper White River (B) in east-central Indiana. Buck Creek was the focus of Water Quality Indiana investigations in 2013. The segment of the Mississinewa River between the towns of Ridgeville in the east and Albany in the west (shown by the red rectangle) was the focus of Water Quality Indiana investigations in 2014. subsequent formation of bypass channels, necessitating excessive portage, reducing recreation, and increasing aquatic stress. Public meetings and direct-mail stakeholder surveys by the Upper Mississinewa River Watershed Management Project (UMRWMP), a community partner of WQI, showed overwhelming concern about logjams and the subsequent flooding and erosion of adjacent farmland (fig. 2).

Water Quality Indiana cohorts combine data collected by students and gathered by community partners, as well as publicly available archival data. Students supplement these data with multimedia collections that include still imagery and videography, maps and interactive graphics, and interviews with stakeholders including landowners and regulators. In fall 2013, students collected data from four sites on Buck Creek, a tributary of the White River, in support of scheduled stream bank restoration activities at the confluence of Buck Creek and the White River (fig. 1). In fall 2014, the focus was four sample sites and a series of ten significant logjams, all on the Upper Mississinewa River (fig. 1), in support of long-term investigations by the UMRWMP.

\section{COURSE DESIGN AND ASSESSMENT METHOD}

I don't learn science by reading chapters out of a book, but I learned a great deal by actually going out to the stream and then taking water back to the lab, working side-by-side with our science majors. The main reason I took the class [is] because it wasn't in a traditional setting.

- Comment by a senior Journalism major about WQI, 2013

A central feature of the WQI course model (fig. 3) is that students self-organize into peer networks focused on, for example, literature research, media production, site

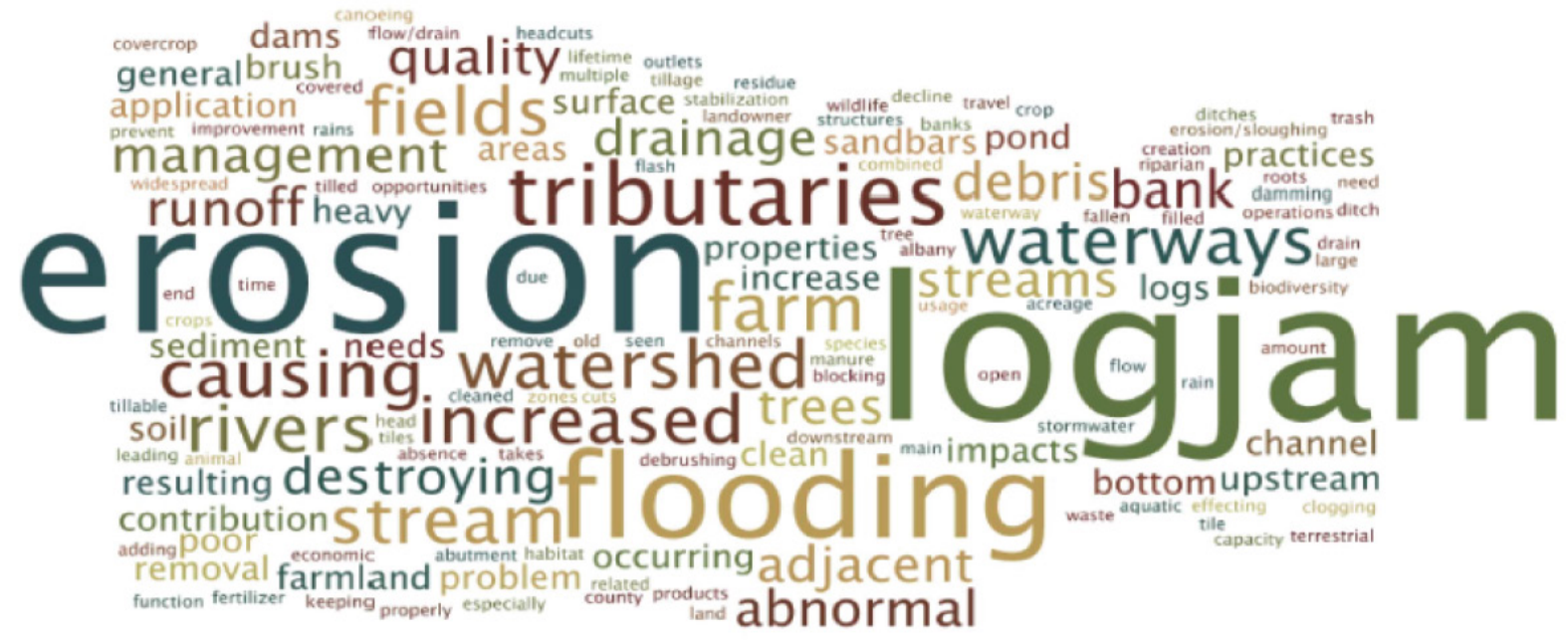

Figure 2. A word cloud representing the concerns listed by landowners in the Upper Mississinnewa River Watershed in response to a targeted survey send by the Upper Mississinnewa River Watershed Management Project (larger words represent a more frequent response). 


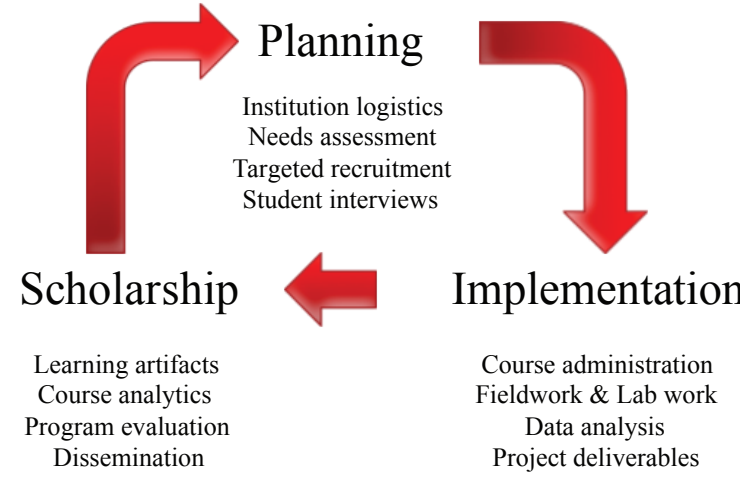

Figure 3. The three-phase implementation of Water Quality Indiana (planning, implementation, and scholarship).

access, sample collection, sample analysis, and quality control (Kuban and others, 2015). Objectives for each cohort target specific goals negotiated between the instructors and community partners (Sprauge and others, 2014; Sroufe and others, 2015). Since 2013, those partnerships have included the UMRWMP, FlatLand Resources (a local environmental consulting firm), and Red Tail Land Conservancy (a nonprofit land trust). Courses included undergraduate and graduate students from dissimilar majors (geology, biology, natural resources, telecommunications, journalism) and two separate colleges at BSU (Science and Humanities; Communication, Information, and Media). The 29 students from the 2013 and 2014 cohorts included 45 percent women and 14 percent from other groups traditionally underrepresented in STEM disciplines.

Student participants are expected to contribute to teams outside their area of expertise: STEM students work on multimedia production and media students participate in sample collection and laboratory analysis. The hope is that cross-disciplinary mentorship among the students allows those familiar with requisite skills to assist those who need more practice. In the experiential PBL framework, student teams coordinate fieldwork, group activities, and product development according to an established timeline. This model allows the instructors to serve as facilitators of science and multimedia content, to manage project workflow, to coordinate with community partners, and handle learning artifacts and assessment instruments.

Learning artifacts and assessment instruments included: 1) a traditional field notebook of all notes and data collected in the course; 2) pretest and posttest questions on STEM/media studies thematic concepts and civic engagement; 3) a synthesis report about the students' view of civic engagement and the importance of transdisciplinary learning; 4) a focus group discussion (moderated by an external colleague) to document student perceptions of expectations and course outcomes; 5) student-designed multimedia "data stories" incorporated into WQl's online resources and disseminated to community partners and media outlets, and at professional conferences; and 6) a formal report by the students that summarizes tasks, methodologies, findings, and recommendations, which is disseminated to community partners.

Here we assess the relative success of this experiential PBL course via analysis of field notes, pre- and posttest questionnaires, the focus group responses, and the synthesis reports. Selected project deliverables illustrate examples of student learning and contributions to the community. Collectively, these products and analyses address each of six learning outcomes (Table 2).

Field Notebook. The study of the natural environment is a visual language where physical surroundings inform comprise a text that must be deciphered (Frodeman, 1995), and the field notebook is an ideal tool in field-based and capstone courses in the geosciences (Compton, 1962). Water Quality Indiana students are tasked to work toward a methodical, descriptive archetype for notetaking that is not "for an audience of one" (Sanjek, 1990, p. 92) and includes notes intended for memory recall, or inscription, intended to dictate literal information, or transcription, and intended to communicate the "coherent representation of an observed cultural reality" (Clifford, 1990, p. 51), or description.

Notebook assessment for each cohort was conducted twice each semester (near mid-term and finals) using a rubric designed for a list of criteria required for each page in the book, whether that page was used for classroom/

Table 2. Association between learning artifacts and learning outcomes for WQI

\begin{tabular}{ll} 
Learning Outcome & Learning Artifact \\
\hline Master transdisciplinary skills. & Pre-post, Focus groups \\
Synthesize information. & Field notebook, Data stories, Formal report \\
Foster effective communication. & Multimedia data stories, Formal report \\
Create sustainable solutions. & Pre-post, Data stories, Formal report \\
Bridging of scale. & Pre-post, Synthesis report, Focus groups \\
Develop a holistic outlook. & Pre-post, Synthesis report, Focus groups \\
Identify professional opportunities. & Focus groups
\end{tabular}


interview notes, field work, field sketches, or laboratory notes (Appendix 1). Scores for each book were normalized to the number of pages students provided, such that the number of notes played a reduced role in the grade. Permission to use the field notebook and assessment scores was solicited in sealed consent forms, opened after final grades were issued. An analysis of grades was conducted by single-tail t-test to analyze whether metadata on student gender or declared major played any role in field notebook scores. A textual analysis of field book pages complemented the statistical results to provide interpretive context.

Pretest/Posttest Questionnaires. Shoemaker (2010) assessed students' knowledge and perceived confidence pertinent to student learning outcomes in a horticulture course. "'Know' refers to performance accuracy, and 'knowing how much they know' relates to confidence" (Lichtenstien and Fischoff, 1977; Pennycook and others, 2017). Knowledge acquired over the course of a semester can speak directly to pedagogical effectiveness, but confidence in that knowledge is also important to assess (Colbeck and others, 2001). Twenge (2013) noted "some students can be too confident" (p. 68); educators should not necessarily associate improved confidence with correct answers. The WQI pretest/posttest questionnaire (Appendix 2) assesses declarative knowledge of a small sampling of water quality and media-related concepts along with a Likert scale gauging perceived confidence in responses to these questions.

For the 2014 cohort, an additional set of Likert scale pretest/posttest questions investigated the students' broader confidence in their ability to create, understand, and explain STEM and media information. Other questions probed the perceived role of community engagement as part of the course (Table 3). This group was asked a further suite of posttest civic engagement questions to understand perception of their connection to the community partners (Table 3 ).

Respondents were anonymous, but were asked to provide metadata on gender, declared major, and academic rank. For the questions on declarative concepts in science and media, the number of correct answers along with the confidence in those answers was recorded as a percentage. For the questions on process, community engagement, and project input, factor analysis and two-tailed tests of significance were conducted in SPSS software to assess whether one or more of the metadata could explain the variation in the results.

Synthesis reports. Near the conclusion of the course, students completed a structured reflexive narrative that required them to consider the learning outcomes for WQI and their program experience (Table 4). This report contributed toward the course grade, and a rubric assessed the degree of thoroughness. Students compose no less than five double-spaced pages for this synthesis report, providing an opportunity to gauge learning and insight into curricular takeaways and phenomena.

Focus Groups. A focus group is an inexpensive and quick way to gather qualitative data from a number of people at one time, and it served as the fourth direct method of assessing WQI. To encourage discussion and to gain access to the points of view of participants, the interviewer must promote a relaxed atmosphere and ask simple questions to encourage discussion (Marshall and Rossman, 2006, p. 114). In this study, a colleagueunaffiliated with course instruction-sought interested students and conducted a 45 -minute focus group session after course completion. Only 5 of 29 students participated, 3 in 2013 and 2 in 2014. Participants were asked four open-ended questions (Table 5).

To assess the focus group transcripts, we used iterative explanation building, or "the gradual building of an explanation" that is "similar to the process of refining a set of ideas" (Yin, 2003, p. 122). This process forces immersive analysis of the qualitative data, and encourages contemplation of other plausible or rival explanations. Protocols followed the five-step analysis process of LeCompte (2000): 1) Tidy up the data; 2) find items in the data; 3 ) create stable sets of items; 4 ) create patterns as a result of the sets; and 5) assemble structures that provide meaning. In the first step, "tidying up permits researchers to make a preliminary assessment of the data set" (LeCompte, 2000, p. 148). Then one searches for "specific things in the data set [to] code, count, and assemble into research results" before they "clump together items that are similar or go together," which becomes the third step (p. 148-149). After this part of the process, "locating patterns involves re-assembling [sets of items] in ways that begin to resemble a coherent explanation or description" (p. 150). The researcher builds an "overall description" to help people "see more clearly how to solve problems, improve programs, assess their effectiveness, or develop theories" (p. 151).

\section{Project Goals}

In this paper, we report on the learning artifacts and assessment data as they relate to the six learning outcomes (Table 2). Of key importance to the WQI program, as well as any other experiential PBL course, is the value students place in procedural knowledge rather than declarative concepts. Specifically, we are interested in the differences among students in generating data and deliverables as practical application of knowledge to realworld problems, and their capacity to interpret scientific 
Table 3. Additonal likert scale questions for the 2014 WQI cohort

Confidence in process and role of community engagement (pre-post)

Scientific process:

- I feel confident in my ability in reading scientific results.

- $\quad$ I feel confident in my ability to understand scientific results.

- I feel confident in my ability to report scientific results.

- $\quad$ I feel confident in my ability to explain to a novice my scientific results.

Media process:

- I feel confident in my ability in creating media products that convey scientific results.

- I feel confident in my ability to understand media reporting protocols.

Community engagement:

- I understand our community partners' role in the community.

- I believe our community partners' role is important in the community.

- $\quad$ I know how our community partner helps the community understand water resaurces.

Civic engagement (post)

Contribution to the community:

- I feel that I made a real contribution to the community.

- I believe the overall project met needs identified by members of the community.

- I believe I did NOT make a positive impact on the community.

- $\quad$ I interacted with people in the community about our overall project.

Project input:

- I felt forced into doing this project.

- I was NOT free to develop or to use my own ideas.

- I had some choice in the creation of the project deliverables.

- I wish I had been given more options about our overall contribution to the community.

output, make meaning of the findings, and communicate them to the public. The forms of this communication are as varied as the students' academic, ethnic, and socioeconomic backgrounds but include public showcases, conference presentations, and online resources.

The collective life stories of WQI students foster discussion and provide many viewpoints through which problem-solving may occur; thus, we use metadata to explore some aspects of learning within this collaboration such as retention of and confidence in declarative and procedural knowledge, confidence in the skills and processes involved in STEM and multimedia, thoughts on civic engagement, and the effectiveness of this PBL learning environment.

\section{RESULTS}

\section{Field notebooks}

Table 6 summarizes scoring data for the 29 field notebooks assessed for WQI courses and sets of students divided into discipline, gender, and the four permutations of these two categories. One-tailed tests of significance between subgroups and for each assessment period are included. Students received significantly lower scores on the final assessment (73\% versus $80 \%, p=0.003$ ).
The STEM students and females performed significantly better than their media and male colleagues, respectively, for the midterm assessment ( $85 \%$ versus $76 \%, p=0.02$; $83 \%$ versus $77 \%, p=0.06$; Table 6 ). This same difference is present, but not statistically significant in the final assessment. These same outcomes do not extend to the combinations of most subgroups except for STEM versus media male students ( $85 \%$ versus $71 \%, p=0.02)$ and female versus male media students ( $82 \%$ versus $71 \%, p$ $=0.05$ ) in the midterm assessment. STEM students are statistically similar when compared by gender for both assessment periods. Female students in both STEM and media studies performed similarly in both assessment periods.

\section{Pre- and postcourse questionnaires}

In 2013, sixteen participants-seven women and nine men-filled out the pretest. The participants divided into eight STEM and eight media students. Seniors (11) were the largest group, followed by three juniors, one sophomore, and one graduate student. For the posttest, six women and eight men completed the questionnaire; two dropped the class after completing the pretest. The participants' majors were in STEM (6) and media studies 
(8). Seniors were the largest group with 78.6 percent (11), followed by two juniors and one sophomore.

The 2014 WQI cohort included sixteen, including six women and ten men, that completed the pretest. The participants were six STEM and ten media students that included seniors (10), sophomores (4), and juniors (4). Six women and eight men completed the posttest, divided into seniors (9), sophomores (3), and juniors (4). These students had majors in STEM (5) and media studies (9).

Declarative Concepts. Table 7 compiles results of the pretest and posttest data related to specific concepts in water quality and media for the 2013 and 2014 cohorts (Appendix 2). In all cases the confidence of students in their answers increased from the course beginning to the end. For the questions regarding media, the increased confidence (82\% to $97 \%$ ) is parallel with an increase in accuracy (65\% to $74 \%$ ). For science questions, however, the average accuracy stays similar (46\%) despite increased confidence (57\% to 83\%). In fact, the accuracy for five of eight science questions decreases from pretest to posttest. The remaining three questions that increased in accuracy dealt specifically with the riparian zone, sediment transport, and sediment erosion-concepts that were major topics in the class.

Confidence in Process and Community Engagement. Table 8 compiles statistical data for the pretest and posttest on scientific and media process and community engagement for the 2014 cohort (Table 3). In all cases, scores increased; Table 9 is the factor analysis results for these same questions. For each set, one factor, student major, was the best solution for the available student metadata with the Chronbach's alpha reliability for the pretest and posttest data of 0.70 and 0.93 for the questions on scientific process, 0.76 and 0.82 for questions on the media process, and 0.59 and 0.88 for questions on community engagement.

For the more reliable posttest data, an independent t-test reveals no difference between STEM and media studies majors for the questions on scientific process; $t(12)=-0.39, p=0.17$. Similarly, the posttest data reveal no difference between STEM and media studies majors for the questions on community engagement; $t(12)=$ $-0.22, p=0.83$. The means for these populations nearly overlap-STEM $(m=0.08 \pm 0.77, n=5)$ and media studies $(m=-0.05 \pm 1.15, n=9)$. In contrast, there is a significant

Table 4. Structure of synthesis report

Students' personal understanding of water quality science:

- Describe what can be typically measured in water-quality data collection.

- What are key takeaways from the data we analyzed this semester?

- How much would you estimate you have learned in this capacity since the beginning of the semester? $(1=$ nothing new; $3=$ about as much as I expected; $5=$ beyond what $\mathrm{I}$ anticipated). Explain your numerical estimate.

- What key concepts do you think will resonate, or "stick", with you after this course concludes?

Students' connection between scientific research \& multimedia production:

- In general, what does literature indicate about science reporting, i.e., journalists covering scientific issues?

- How much would you estimate you have learned about "the other side" since the beginning of the semester? ( 1 = nothing new; $3=$ about as much as I expected; $5=$ beyond what I anticipated). Explain your numerical estimate.

Students' opinions of the best \& most challenging part(s) of WQI:

- What was the best part of the immersive design, or nature, of this interdisciplinary course?

- What was the most challenging part of the immersive design, or nature, of this interdisciplinary course?

Table 5. Focus group questions

What did you think of the combination of media and science students in this interdisciplinary course?

To what extent were the course objectives met, in your opinion? What could have been done as a part of the course to improve this?

What do you now understand about your own field that you didn't know before this course?

What do you now understand about the "other" field that you didn't know before this course? 


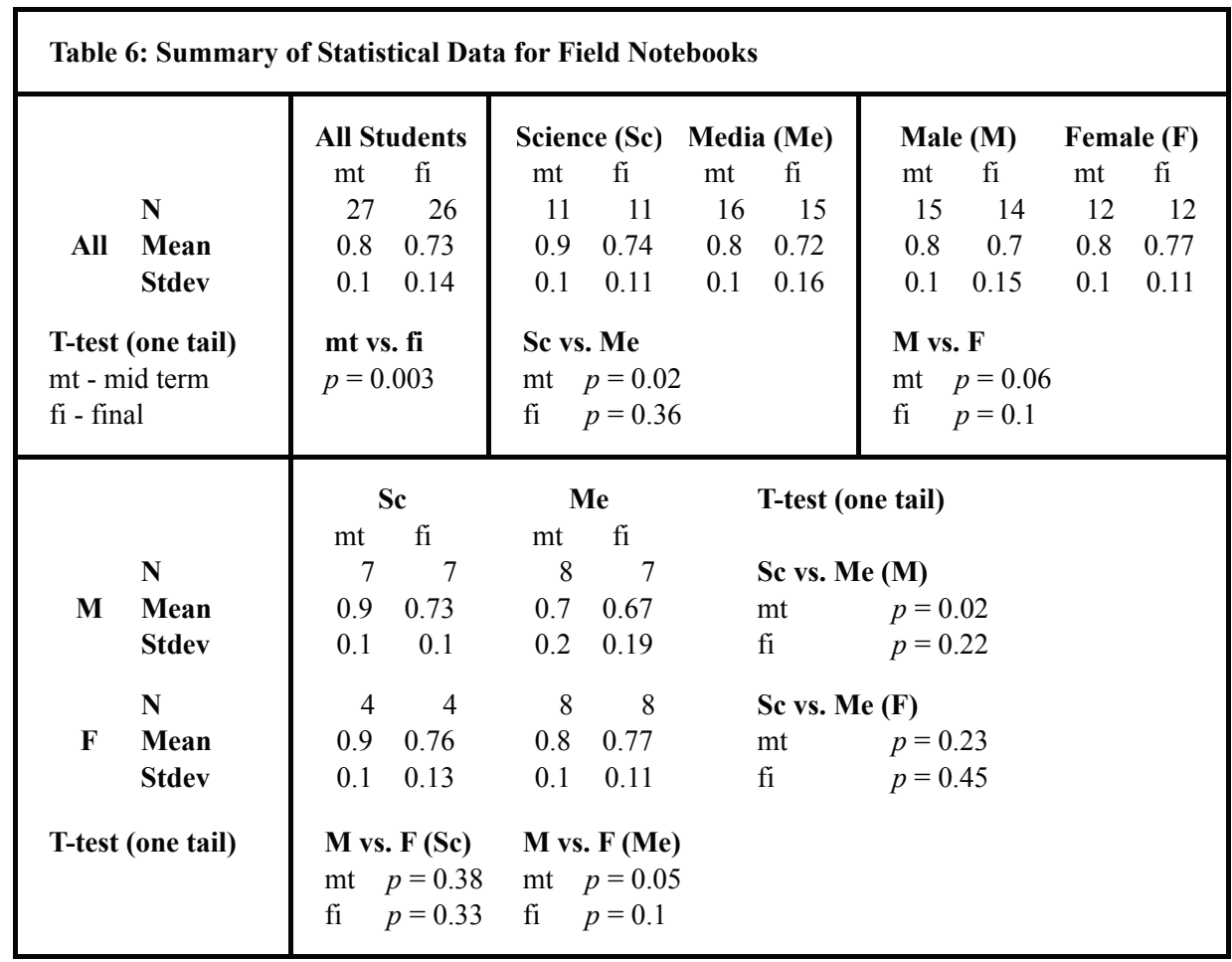

difference in the posttest data for the questions on media process, $t(12)=5.5, p=0.000$, with population means in STEM $(m=-1.09 \pm 0.74, n=5)$ and media studies $(m=$ $0.61 \pm 0.43, n=9$ ) that are sizably different.

Civic engagement. The posttest data for the questions on community engagement and tabulated in Table 8 for the 2014 cohort and were processed by Varimax factor analysis in SPSS (Table 10). One factor, gender, was the best solution for the available student metadata with a Chronbach's alpha of 0.86 for the questions on contributions to the community and 0.73 for questions on project input. This test shows that men and women looked at the "Community and Choices" slightly differently. Men looked at their impact to the community more positively than women did. However, there were no differences between majors; $\mathrm{t}(6)=-0.37, \mathrm{p}=0.97$ ).

\section{Synthesis reports.}

Qualitative textual analysis of synthesis reports from 2013 and 2014 revealed patterns in solicited narrative items from Table 4. Regarding the understanding of science, half included declarative elements, including newfound vocabulary such as "buffer strip" and "confluence." Other examples include a deeper understanding of water pollution and greater familiarity with the types of tests that monitor water quality. Not as common in the aggregate replies but still evident was evidence of procedural knowledge. In particular, students mentioned learning more about the process of sampling water and the steps observed for proper note-taking in the field.

Regarding the connection between science and journalism, more than half criticized or offered personal opinions about lackluster science reporting, writing that "journalists are not good at scientific reporting" or that "journalists do not have a sense on how to report" science. Some acknowledged a "huge disconnect on what journalists report and the actual facts that the scientific studies show," while others suggested a more proactive solutionscientists and journalists "need to work hand-in-hand to bridge the gap." Five students mentioned technical media skills they acquired through the WQI project, including taking pictures, video, editing, lighting, delivery posture and pronunciation, and breaking down complex information. The same number of students identified technical science skills gained, including taking samples, testing $\mathrm{pH}$, maintaining chain of custody, and analyzing raw data.

More than half specifically wrote "immersive" in their replies, indicating that the hands-on nature of the course appealed to them. About the same number also mentioned "stepping away from regular course work" in order to "look at the problems from another mindset" as the best part of the course. However, that also led to some challenges-teamwork being cited most often. Not surprisingly, student cited that communication suffered at times. Time was also mentioned-the amount of time invested, as well as time management in order to complete tasks as necessary. 


\begin{tabular}{|c|c|c|c|c|c|c|c|c|c|c|c|}
\hline $\mathbf{Q}$ & \multicolumn{2}{|l|}{ Topic } & \multicolumn{3}{|c|}{ Pretest, $\mathrm{N}=32$} & \multicolumn{4}{|c|}{ Posttest, $\mathbf{N}=\mathbf{2 8}$} & & \\
\hline \multicolumn{2}{|c|}{ Water Quality Questions } & Correct & Certain & \multicolumn{2}{|c|}{ Think correct Combined } & \multicolumn{2}{|c|}{ Correct Certain } & \multicolumn{2}{|c|}{ Think correct Combined } & \multirow{2}{*}{\multicolumn{2}{|c|}{$\begin{array}{c}>\text { Acc }>\text { Conf } \\
*\end{array}$}} \\
\hline 1 & NEPA & $31.3 \%$ & $6.3 \%$ & $43.8 \%$ & $50.0 \%$ & $28.6 \%$ & $32.1 \%$ & $57.1 \%$ & $89.3 \%$ & & \\
\hline 2 & non-point source & $78.1 \%$ & $21.9 \%$ & $43.8 \%$ & $65.6 \%$ & $75.0 \%$ & $35.7 \%$ & $53.6 \%$ & $89.3 \%$ & & $*$ \\
\hline 3 & dissolved oxygen & $53.1 \%$ & $18.8 \%$ & $43.8 \%$ & $62.5 \%$ & $50.0 \%$ & $21.4 \%$ & $50.0 \%$ & $71.4 \%$ & & * \\
\hline 4 & tile drains & $37.5 \%$ & $18.8 \%$ & $40.6 \%$ & $59.4 \%$ & $28.6 \%$ & $42.9 \%$ & $42.9 \%$ & $85.7 \%$ & & $*$ \\
\hline 5 & riparin zone & $40.6 \%$ & $6.3 \%$ & $25.0 \%$ & $31.3 \%$ & $42.9 \%$ & $25.0 \%$ & $53.6 \%$ & $78.6 \%$ & $*$ & $*$ \\
\hline 6 & sediment transport & $46.9 \%$ & $25.0 \%$ & $28.1 \%$ & $53.1 \%$ & $71.4 \%$ & $42.9 \%$ & $28.6 \%$ & $71.4 \%$ & $*$ & $*$ \\
\hline 7 & steam velocity & $43.8 \%$ & $15.6 \%$ & $50.0 \%$ & $65.6 \%$ & $35.7 \%$ & $57.1 \%$ & $35.7 \%$ & $92.9 \%$ & & * \\
\hline 0 & sediment erosion & $34.4 \%$ & $28.1 \%$ & $37.5 \%$ & $65.6 \%$ & $35.7 \%$ & $46.4 \%$ & $39.3 \%$ & $85.7 \%$ & $*$ & $*$ \\
\hline & Summary & $45.7 \%$ & $17.6 \%$ & $39.1 \%$ & $56.6 \%$ & $46.0 \%$ & $37.9 \%$ & $45.1 \%$ & $83.0 \%$ & & \\
\hline \multicolumn{2}{|c|}{ Media Questions } & \multicolumn{4}{|c|}{ Correct Certain Think correct Combined } & \multicolumn{4}{|c|}{ Correct Certain Think correct Combined } & \multicolumn{2}{|c|}{$>$ Acc $>$ Conf } \\
\hline 1 & attribution & $81.3 \%$ & $56.3 \%$ & $25.0 \%$ & $81.3 \%$ & $89.3 \%$ & $67.9 \%$ & $28.6 \%$ & $96.4 \%$ & * & $*$ \\
\hline 2 & quotes & $28.1 \%$ & $56.3 \%$ & $28.1 \%$ & $84.4 \%$ & $50.0 \%$ & $67.9 \%$ & $32.1 \%$ & $100.0 \%$ & $*$ & $*$ \\
\hline 3 & rule of thirds & $71.9 \%$ & $59.4 \%$ & $21.9 \%$ & $81.3 \%$ & $75.0 \%$ & $60.7 \%$ & $35.7 \%$ & $96.4 \%$ & $*$ & $*$ \\
\hline 4 & shot sequence & $50.0 \%$ & $25.0 \%$ & $50.0 \%$ & $75.0 \%$ & $67.9 \%$ & $57.1 \%$ & $39.3 \%$ & $96.4 \%$ & $*$ & $*$ \\
\hline 5 & interview questions & $93.8 \%$ & $68.8 \%$ & $25.0 \%$ & $93.8 \%$ & $100.0 \%$ & $82.1 \%$ & $17.9 \%$ & $100.0 \%$ & $*$ & $*$ \\
\hline 6 & video editing & $12.5 \%$ & $21.9 \%$ & $53.1 \%$ & $75.0 \%$ & $25.0 \%$ & $50.0 \%$ & $46.4 \%$ & $96.4 \%$ & $*$ & $*$ \\
\hline 7 & natural sound & $93.8 \%$ & $56.3 \%$ & $25.0 \%$ & $81.3 \%$ & $92.9 \%$ & $78.6 \%$ & $17.9 \%$ & $96.4 \%$ & & $*$ \\
\hline \multirow[t]{2}{*}{8} & truthful reporting & $87.5 \%$ & $65.6 \%$ & $21.9 \%$ & $87.5 \%$ & $92.9 \%$ & $85.7 \%$ & $10.7 \%$ & $96.4 \%$ & $*$ & $*$ \\
\hline & Summary & $64.8 \%$ & $51.2 \%$ & $31.3 \%$ & $82.4 \%$ & $74.1 \%$ & $68.8 \%$ & $28.6 \%$ & $97.3 \%$ & & \\
\hline
\end{tabular}

\section{Focus Groups}

Water Quality Indiana participants valued the process, or the procedural knowledge, involved with the PBL environment as opposed to the declarative knowledge associated with it. For example, from one student:

I actually learned quite a bit about the interviewing process, how to set them up and how to actually make the scene look when you're meeting someone, which is not something that any of my science classes have ever even remotely touched.

Similar themes were present throughout the transcript and transcended disciplinary divides. For example, a multimedia student explained that "being out in the field and...able to know what to look for in terms of reporting" was an important outcome. A science student explained that they "learned a lot about how you want people to see things-not just how you wanted to see it." This reflects other comments from participants indicating their interest in learning more about software programs that allow for video and audio editing as well as storytelling.

Moreover, students noted improved confidence later in the semester. "At the beginning, I was definitely a little weary [sic] of the entire situation just because it was the first time with the class. As it went on, though, [it] definitely came together, and I started to get a little more confidence." From another student: "I've actually been a little bit more confident in talking with some of my professors."

With regards to the learning outcomes, most dwelled on the presentation of scientific findings and their multimedia deliverables that explained the importance of those results. Two student statements encapsulate this success. One student in multimedia studies indicated that "taking [scientific] information and making it available for the normal, non-scientific person is something that we also did and that was also a success." Another multimedia studies student mused: "lower-level journalism classes do theoretical work. It doesn't necessarily feel real. But after having done something like this...you feel the full force of the work and research and interviews and publishing... I think just seeing the whole process from day one [including] presenting the website and scientific models....was just a really cool process to see, and I think it gives you a different perception...."

In terms of course challenges, participants identified the need for additional time. In short, they said they needed more time to not be overwhelmed by the process that they ultimately indicated as valuable. They also desired more contact with the community partner, wanting more time to speak with them and to understand the role that nonprofits play in the maintenance and restoration of local water quality.

\section{DISCUSSION}

A central question about experiential PBL is how collaborative environments that combine students from a range of disciplines influence metacognitive reflexivity and, therefore, knowledge and scholarship. For WQI, which includes students from the natural sciences and multimedia production, one outcome would be an improved comprehension of the methods and deliverables 
Table 8. Varimax factor analysis of scientific and media process, community engagment, and student metadata.

\begin{tabular}{|ll|r|r|r|r|r|r|}
\hline & & \multicolumn{3}{c}{ Pretest } & \multicolumn{3}{c|}{ Posttest } \\
\hline \multirow{2}{*}{ Questions } & Home department & $\mathrm{N}$ & Mean & Stdev & $\mathrm{N}$ & Mean & Stdev \\
\hline \multirow{2}{*}{ Sommunity } & Journalism & 10 & 0.21 & 0.82 & 9 & -0.05 & 1.15 \\
& Geology & 6 & -0.34 & 1.25 & 5 & 0.08 & 0.77 \\
\hline \multirow{2}{*}{ Media } & Journalism & 10 & -0.29 & 0.99 & 9 & -0.28 & 1.07 \\
& Geology & 6 & 0.48 & 0.90 & 5 & 0.50 & 0.68 \\
\hline \multirow{2}{*}{ Journalism } & 10 & 0.52 & 0.64 & 9 & 0.61 & 0.43 \\
& Geology & 6 & -0.87 & 0.90 & 5 & -1.09 & 0.74 \\
\hline
\end{tabular}

Pretest

Posttest

Levene's test T-test (two-tailed) Levene's test T-test (two-tailed)

\begin{tabular}{|l|c|c|c|c|c|c|c|c|c|c|}
\hline Questions & $\mathrm{F}$ & $p$ & $\mathrm{t}$ & $\mathrm{df}$ & $p$ & $\mathrm{~F}$ & $p$ & $\mathrm{t}$ & $\mathrm{df}$ & $p$ \\
\hline Community & 0.02 & 0.90 & 0.82 & 14 & 0.30 & 0.42 & 0.53 & -0.22 & 12 & 0.83 \\
\hline Science & 1.07 & -1.54 & 0.99 & 14 & 0.15 & 0.54 & -1.94 & 0.39 & 12 & 0.17 \\
\hline Media & 0.20 & 3.65 & 0.64 & 14 & 0.00 & 3.14 & 0.10 & 5.50 & 12 & 0.00 \\
\hline
\end{tabular}

expected in both scientific and media outlets. This discussion synthesizes the available assessment data to answer that question, presents some aspects of what students value in this course framework, and explores how participating student performance differs.

\section{Does experiential PBL foster learning and confidence?}

At first glance, the results suggest that field notebooks did not increase metacognition (Table 6); however, it is important to realize that the nature of experiential PBL courses impose compressed time frames for data collection, synthesis, and dissemination. These courses also include deadlines, reports, and a showcase of course outcomes, all alongside obligations and examinations for other courses. Therefore, some scores may reflect individual prioritization and stress cited in the synthesis reports, which may support a shift toward PBL opportunities that span the academic year as opposed to one semester.

Similarly, pretest and posttest accuracy on the declarative concepts related to water quality did not increase during the class with the exception of specific topics directly related to field investigations (Table 7). However, focus group transcripts reveal an increased understanding of the scientific process and suggested that learning reached farther than the target goals of the class projects and addressed the learning outcomes in Table 1. In particular, the synthesis reports and focus group comments suggested that students had a broader understanding of methods of scientific communication and more holistic means to understand water quality.
In contrast, accuracy improved among the media-based questions (Table 7). These results could reflect the structure of the course; preparations for a public showcase dominated the last few weeks and included intensive multimedia production and presentation. The synthesis reports and focus group participants identified these process-based activities such as collecting interviews and using software for multimedia storytelling as valuable evidence of learning outcomes (Table 1), including mastery of transdisciplinary skills, public communication, and the need to bridge between local events and impacts on the broader community.

Broadly, the synthesis report and focus group data reveal that procedural knowledge in water quality may have improved among student cohorts, citing an increased ability to comprehend the process, or how to do something, but not necessarily the specific water quality concepts assigned. The 2014 data from the confidence-in-science and media-process questions support this statement (Table 9). Interestingly, the perceived confidence of students in their posttest answers for the declarative concepts increased for every question in water quality and media studies (Table 7), consistent with Shoemaker's (2010) study. This result could arise from a conditioned notion that students believe that they should know more than they actually do when they complete a course. In the case of WQI, immersion in fieldwork and laboratory analysis may lead to a misplaced perception of expertise, which signifies the importance of content delivery (not necessarily lecture) in paired or foundation courses. In other words, student education in STEM should not rely solely on experiences or PBL as the modes of learning. 


\begin{tabular}{|c|c|c|c|c|}
\hline 2014 cohort (Likert scale 1 - 4) & $\begin{array}{c}\text { Pre } \\
\text { Mean }\end{array}$ & $\begin{array}{l}\text { est } \\
\text { tdev }\end{array}$ & $\begin{array}{c}\text { Post } \\
\text { Mean }\end{array}$ & $\begin{array}{l}\text { est } \\
\text { tdev }\end{array}$ \\
\hline Process and Community Role & $\mathrm{N}=$ & & $\mathrm{N}=$ & \\
\hline $\begin{array}{l}\text { Science process } \\
\text { reading results } \\
\text { understand results } \\
\text { report results } \\
\text { explain results } \\
\text { Media process } \\
\text { creating products } \\
\text { understand protocols } \\
\text { Community engagement } \\
\text { understand role } \\
\text { role is important } \\
\text { know function }\end{array}$ & $\begin{array}{l}3.06 \\
3.25 \\
\\
3.06 \\
3.44 \\
2.94\end{array}$ & $\begin{array}{l}0.70 \\
0.50 \\
0.70 \\
0.60 \\
\\
0.90 \\
0.70 \\
\\
\\
0.56 \\
0.50 \\
0.66\end{array}$ & $\begin{array}{l}3.14 \\
3.57 \\
\\
3.57 \\
3.57 \\
3.50\end{array}$ & $\begin{array}{l}0.85 \\
0.70 \\
0.59 \\
0.70\end{array}$ \\
\hline \multicolumn{5}{|l|}{ Civic Engagement } \\
\hline $\begin{array}{l}\text { Contributions to community } \\
\text { I made contribution } \\
\text { project met needs } \\
\text { I did not make positive } \\
\text { Project input } \\
\text { felt forced } \\
\text { not free to develop } \\
\text { some choice } \\
\text { more options }\end{array}$ & & & $\begin{array}{l}1.63 \\
1.38 \\
3.13 \\
2.25\end{array}$ & $\begin{array}{l}0.33 \\
0.50 \\
0.48 \\
\\
0.48 \\
0.48 \\
0.78 \\
0.66\end{array}$ \\
\hline
\end{tabular}

\section{How do WQI students differ?}

The field notebook represents one measure of how students synthesize scientific findings (Table 2). The results reveal differences in scores based upon declared major and gender, which may distinguish between styles of note taking among students (Table 6). While the use of field notebooks is a common practice in the geosciences and is one factor that can explain the scoring difference between groups, the scoring difference based upon gender is less clear. Curiously, the limited posttest data on civic engagement indicates that it did not matter what major the students identified, but it did matter if they were male or female on how they felt they positively affected the community-female students were more critical of that role than their male counterparts (Table 9). Selected pages within the field notebooks provide some context for the scoring patterns. Despite a clear grading rubric, male students more frequently disregarded instructions than their female classmates. This is particularly well defined with male students from media disciplines where note-taking more frequently consisted of short bullet points including names and contact information, key quotes, and other information (fig. 4); students in media often rely on personalized shorthand, audio recordings, or memory (Adams and Hicks, 2001, p. 89-90). The impression is that the notes are rushed and sometimes archived after a conversation or sample collection. In contrast, female students scored better across both disciplines. Pages of their notes, while in some cases missing information, tended to be more clearly organized and meticulously written (fig. 4). This follows the results of other studies of gender differences in note-taking, such as Reddington (2011), in which women demonstrated increased transcription fluency, working memory, verbal ability, and conscientiousness.

Interestingly, STEM and media students did not respond in a significantly different way on the pretest and posttest questions on scientific process. However, the means for STEM ( $m=0.50 \pm 0.68, n=5)$ and media studies $(m=-0.28 \pm 1.07, n=9)$ students suggests that a larger sample size could reveal that media studies majors were still not confident in their science skills at the end of the course (Table 9). In contrast, the questions on community engagement, despite a lack of statistical significance, have pretest means that suggest a more engaged group of media studies majors and posttest means that converge. With a larger sample size, this could mean that all WQI students learned more about the community where they lived.

Regarding students' confidence in multimedia process, there was a significant difference between declared majors. The pretest and posttest means for media studies majors were 0.52 and 0.61 , while the means for STEM majors were -0.87 and -1.09, a difference in opposite directions (Table 9). This shows that media studies majors were still more confident in creating media and reporting than STEM majors after completing the course. It could mean that media studies majors throughout the semester became more confident in their multimedia skills, while STEM majors became less confident. This could show a positive learning curve in that STEM majors realized that there was more to reporting and effectively communicating scientific results than originally thought.

Table 10. Varimax factor analysis of community role and project choices

\begin{tabular}{|c|c|c|c|c|c|c|c|c|c|}
\hline & & \multicolumn{3}{|c|}{ Posttest } & \multicolumn{2}{|c|}{ Levene's test } & \multicolumn{3}{|c|}{ T-test (two-tailed } \\
\hline Questions & Gender & $\mathrm{N}$ & Mean & Stdev & $\mathrm{F}$ & $p$ & $\mathrm{t}$ & $\mathrm{df}$ & $p$ \\
\hline \multirow{2}{*}{ Community } & Male & 4 & 0.63 & 1.10 & \multirow[t]{2}{*}{4.49} & \multirow[t]{2}{*}{0.08} & \multirow[t]{2}{*}{2.23} & \multirow[t]{2}{*}{6} & \multirow[t]{2}{*}{0.07} \\
\hline & Female & 4 & -0.63 & 0.27 & & & & & \\
\hline \multirow{2}{*}{ Choices } & Male & 4 & -0.11 & 1.24 & \multirow[t]{2}{*}{2.56} & \multirow[t]{2}{*}{0.16} & \multirow[t]{2}{*}{-0.29} & \multirow[t]{2}{*}{6} & \multirow[t]{2}{*}{0.78} \\
\hline & Female & 4 & 0.11 & 0.87 & & & & & \\
\hline
\end{tabular}


It could also show that the media studies majors knew more than they thought. Both directions could indicate changes in metacognition resulting from a transdisciplinary learning environment.

\section{What do WQI students value?}

Vocational skills and a deeper comprehension about subject areas within and beyond a college major augments a student's marketability (Pierce and Miller, 2007; Fahmy, 2008; Neidobf, 2008; Goudreau, 2012; Pitt and Tepper, 2012; Jett, 2013); the WQI learning environment fosters career exploration and skill development in the geosciences and multimedia (Table 1). While at BSU, one student returned as a community partner, two as paid course assistants, two others continued project work as independent studies. After graduation, two alumni pursued graduate degrees in geosciences and at least four found employment in STEM fields.

Posttest data on scientific and multimedia process suggest that WQI students were more comfortable with requisite skills required for each field (Table 8). From the synthesis report and focus group data, WQI students appreciated the hands-on nature of the course and the transdisciplinary method of finding solutions to realworld problems-in line with course learning outcomes (Table 1). These solutions can have tangible outcomes. For example, deliverables from the 2014 cohort on the location and severity of logjams in the Mississinewa River watershed (Figure 2) were instrumental to a Lake and River Enhancement grant from the Indiana Department Environmental Management to assist with logjam removal and farmland flooding.

Posttest results on the community engagement questions from 2014 (Table 3) suggest that students may have already understood that government agencies and nonprofit organizations are valuable to the study and conservation of water resources, but gained a better understanding of their function (Table 8). Overall, students felt that the course met objectives and contributed to the community, but were mixed in their view of options provided to contribute.

The synthesis report data demonstrate that WQI students were critical of scientific reporting and appreciated the opportunities to develop media stories related to their investigations. For example, a student-produced radio segment aired on Indiana Public Radio in 2013 that included interviews with community partners and local stakeholders to highlight stream restoration along the White River in Yorktown, Indiana. Student contributions to WQI in our 2013 and 2014 iterations resulted in a student-produced course website, exposure in regional media (newspapers and radio), conference abstracts (Borgmann and others, 2014; Florea and Kuban, 2014; Kuban and others, 2014; Sprague and others, 2014; Saydshoev and others, 2014; Kuban and Florea, 2015; Purtha and others, 2015; Sroufe and others, 2015), a peer-reviewed journal article (Kuban and others, 2015), and an invitation to the White House Water Summit in 2016. Since then, student contributions to WQI's objectives have led to two regional Emmy nominations, film-production awards, film festival screenings, and additional publications in academic and trade publications.

\section{CONCLUSIONS}

The WQI program sharply contrasts with a traditional classroom education. It is (by design) student-driven, community-focused, and modular. Its transdisciplinary implementation encourages peer teaching and broad dissemination of course products; collaborations, therefore, can span institutional boundaries. For this learning environment focused on concepts of water quality and media that relies significantly on engagement with community partners and stakeholders, our assessment to date identifies points of success and improvement for the achievement of learning outcomes.
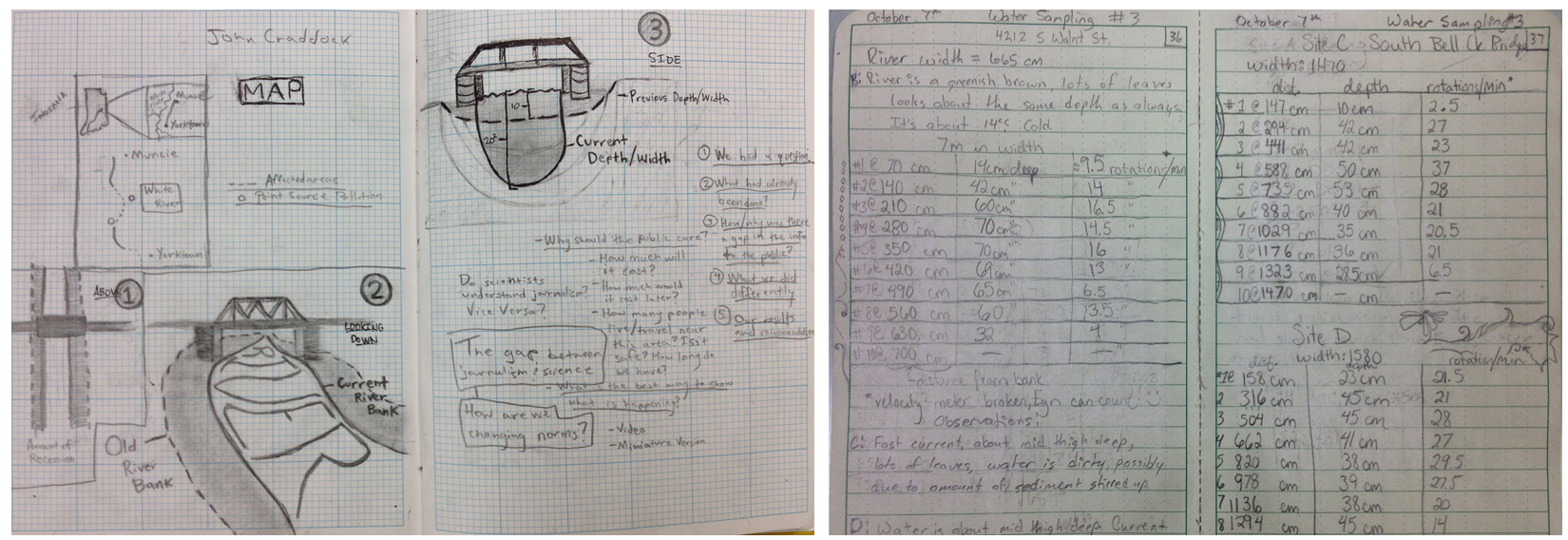

Figure 4. Representative pages from the field notebooks of students in multimedia (left) and STEM (right) studies. 
1. Students from vastly different academic backgrounds can work effectively in groups when they have a clearly defined project and goals aimed at solutions to real-world problems.

2. There is a pervasive distinction in note-taking style and detail in the field, the lab, and during interviews based on gender and academic background; female-identifying and STEM students adhered more closely to the rubric and were significantly more detailed and meticulous than male-identifying and media counterparts.

3. Academic background does matter, not only for context and relevance, but also for the experience with and confidence in the requisite skills and processes in conducting investigations in STEM and media studies topics.

4. Experiential PBL learning environments provide an excellent platform to develop tangible workforce skills, but time constraints imposed by academic calendars and project deadlines can limit acquisition of declarative knowledge of those topics.

5. Despite the stationary or decreased scores in many concepts of water quality by the end of the course, student confidence in answers strongly improved, illustrating a cognitive dissonance between student metacognition and thematic expertise that should act as a caution to both students and faculty concerning curricular engagement diversity.

Finally, a recurring theme of "immersive learning" endeavors, such as WQI, is the perceived negative impact on the careers of young faculty focused on significant grants, high-impact publications, and positive student evaluations to achieve tenure. The authors, who began this pedagogical initiative as young career faculty and have both since attained promotion and tenure, are acutely aware of this stress point and have modeled WQI as a consulting business through which students work for community-partner clients with guidance from faculty. Resulting student deliverables can leverage value-added to a several aspects of a faculty portfolio, not only in teaching and service, but also through purposeful publication and media presence.

\section{ACKNOWLEDGEMENTS}

Assessment metrics for this study were approved for collection and use under Institutional Review Board (IRB) Protocol 524774-1. Funding and support for this project included the Indiana Space Grant Consortium, the BSU Provost Immersive Learning Fund, and the Virginia B. Ball Center for Creative Inquiry. Building Better Communities at BSU provided additional project support. The Water Quality Indiana project would not be possible without significant collaborations with our community partners including Colby Gray of the Upper Mississinewa River Watershed Management Project, Phil Tevis of FlatLand Resources, and Kelly Borgmann of Red Tail Conservancy. Many thanks are also due to the colleagues, students, and landowners without whom this project would not have been possible. We also thank Kyla Cox-Deckard and Cynthia Fadem for their kind reviews of this manuscript.

\section{REFERENCES}

Adams, S., and Hicks, W., 2001, Interviewing for journalists: London, Routledge.

Baldoni, J., 2010, The importance of resourcefulness: Harvard Business Review, URL at http://blogs.hbr.org/2010/01/ leaders-can-learn-to-make-do, accessed March 20, 2014.

Barrows, H., and Tamblyn, R., 1976, An evaluation of problem-based learning in small groups utilizing a simulated patient: Journal of Medical Education, v. 51, no. 1, p. 52-54.

Beckman, M., and Wood, D., 2016, The role of community-based research in achieving community impact, in Beckman, M., and Long, J. F., eds., Community-based research-teaching for community impact: Sterling, Va., Stylus, p. 33-49.

Bhattacharya, A., 2012, Nine ways scientists demonstrate they don't understand journalism: The Guardian, at URL http:// www.guardian.co.uk/science/blog/2012/jan/17/scientists-journalism/print, accessed March 24, 2014.

Blumenfeld, P., Soloway, E., Marx, R., Krajcik, J., Guzdial, M., and Palincsar, A., 1991, Motivating project-based learningsustaining the doing, supporting the learning: Educational Psychologist, v. 26, no. 3-4, p. 369-398.

Borgmann, K., May, R., Hutchinson, D., Hayes, D., Cope, B., Florea, L., and Kuban, A. 2014, Informing the public through multimedia outlets-how a team of interdisciplinary students aided in the understanding of local water quality issues: Geological Society of America Abstracts with Programs, v. 46.

Brieburd, S., 2017, 4 simple tactics to engage better with Gen Z students: Corwin Connect, at URL https://corwin-connect.com/2017/09/4-simple-tactics-engage-better-genz-students/, accessed

May 9, 2019.

Cavanagh, S., 2020, How to make your teaching more engaging: Chronicle of Higher Education, at URL https://www. chronicle.com/interactives/advice-teaching, accessed June 3, 2020.

Clifford, J., 1990, Notes on (field) notes, in Sanjek, R., Fieldnotes-the makings of anthropology: Ithaca, N.Y., Cornell University Press. 
Colbeck, C., Cabrera, A., and Terenzini, P., 2001, Learning professional confidence-linking teaching practices, students' self-perceptions, and gender: Review of Higher Education, v. 42, p. 324-352.

Compton, R., 1962, Manual of field geology: New York, John Wiley \& Sons.

Crawford, C., Lydy, M., and Frey, J., 1996, Fishes of the White River Basin, Indiana: U.S. Geological Survey Water-Resources Investigations Report No. 96-4232.

Duch, B., 1995, Problem-based learning-bringing the real world into the physics classroom: Announcer, v. 25, no. 2, p. 55.

Fahmy, S., 2008, How online journalists rank importance of news skills: Newspaper Research Journal, v. 29, p. 23-39.

Finkle, S., and Torp, L., 1997, Problems as possibilities-transforming garbage into gold, in Jones, B. F., Rasmussen, C. M., and Moffitt, M. C., eds., Real-life problem solving-a collaborative approach to interdisciplinary learning: Washington, D.C., American Psychological Association, p. 192-207.

Florea, L. J., and Kuban, A. J., 2014, Water quality research through the lens of environmental journalism-the role of immersive learning: Geological Society of America Abstracts with Programs, v. 46, no. 3, p. 88.

Fox, G. A., Wilson, G. V., Periketi, R. K., and Cullum, R. F., 2006, Sediment Transport Model for Seepage Erosion of Streambank Sediment: Journal of Hydrologic Engineering, v. 11, no. 6, p. 603-611.

Fox, G.A., Wilson, G. V., Simon, A., Langendoen, E. J., Akay, O., and Fuchs, J. W., 2007, Measuring streambank erosion due to groundwater seepage: correlation to bank pore water pressure, precipitation and stream stage: Earth Surface Processes and Landforms, v. 32, no. 10, p. 1558-1573. DOI:10.1002/esp.1490, 32:447-459.

Fox, S., 2011, Data quality and education: Federation of Earth Science Information Partners (ESIP) Summer meeting, July 12-15, 2011, Santa Fe, NM.

Freire, P., 2000, Pedagogy of the oppressed, 30th anniversary edition: New York, Continuum International Publishing Group, Inc..

Frodeman R., 1995, Geological reasoning-geology as an interpretive and historical science: Geological Society of America Bulletin 107, p. 960-968.

Giroux, H., 2010, Rethinking education as the practice of freedom-Paulo Freire and the promise of critical pedagogy, at URL http://www.truth-out.org/archive/ item/87456, accessed March 20, 2014.

Goudreau, J., 2012, Top 10 tips for young aspiring journalists: Forbes, Nov. 9, at URL http://www.forbes.com/sites/ jennagoudreau/2012/11/09/top-10-tips-for-young-aspiring-journalists, accessed Feb. 9, 2021.
Indiana Department of Environmental Management (IDEM), 2001, Mississinewa River Watershed Restoration Action Strategy, Part I-characterization and responsibilities, 50 p., https://www.in.gov/idem/nps/files/wras_mississinewa_part1.pdf, accessed February 21, 2021.

lyengar, S., and Massey, D., 2018, Scientific communication in a post-truth society: Proceedings of the

National Academy of Sciences of the United States of America, v. 116, no. 16, p. 7,656-7,661. https://doi. org/10.1073/pnas.1805868115

Jett, B., 2013, April 4, Research shows benefit to double majoring: The Daily lowan, April 4, URL at https://dailyiowan.com/2013/04/04/research-shows-benefit-to-double-majoring/, accessed February 21, 2021.

Kolb, D., and Boyatzis, R., 1984, Experiential learning theoryprevious research and new directions: Perspectives on cognitive, learning, and thinking styles: New Jersey, Lawrence Erlbaum.

Kuban, A. J., Apsley, S., Kissel, H., Rodriquez, I., and Sipes, N., 2019, Crystal Clear-an interdisciplinary, immersive-learning short documentary about water: Indiana Geological and Water Survey, Indiana Journal of Earth Sciences, v. 1. DOI 10.14434/ijes.vli0.27034

Kuban, A., and Florea, L., 2015, Water quality within the Upper Mississinewa River of East-Central Indiana-a cross-college collaboration enhancing public understanding of science through immersive learning: Geological Society of America Abstracts with Programs, v. 47.

Kuban, A. J., O'Malley, M., and Florea, L. J., 2015, Students' knowledge and perceived confidence in an interdisciplinary experiential-learning environment: Journal of Community Engagement and Higher Education, v. 6, no. 2, p. 30-38.

Kuban, A., Florea, L., O'Malley, M., and May, R., 2014, Water quality research through the lens of environmental journalism-assessment of students' knowledge and perceived confidence: Geological Society of America Abstracts with Programs, v. 46.

LeCompte, M., 2000, Analyzing qualitative data: Theory into Practice, v. 39, p. 146-154. DOI: 10.1207/ s15430421tip3903_5

Lichtenstien, S., and Fischoff, B., 1977, Do those who know more also know more about how much they know? Organizational Behavior Human Performance, v. 20, p. 159-183.

Marr, B., 2019, The 10 vital skills you will need for the future of work: Forbes, at URL https://www.forbes.com/sites/ bernardmarr/2019/04/29/the-10-vital-skills-you-willneed-for-the-future-of-work/\#62d7194b3f5b, accessed June 3, 2020.

Marshall, C., and Rossman, G., 2006, Designing qualitative research: Thousand Oaks, Cal., Sage Publications, Inc. 
McAdams, M., 2012, Don't just teach skills, train young journalists to be lifelong learners: Nieman Journalism Lab, at URL http://www.niemanlab.org/2012/09/mindy-mcadamsdon't-just-teach-skills-train-young-journalists-to-be-lifelong-learners, accessed September 17, 2012.

Mitchell, T., 2008, Traditional vs. critical service-learningengaging the literature to differentiate two

Models: Michigan Journal of Community Service Learning, v. 14 , no. 2, p. 50-65.

National Association of Colleges and Employers (NACE), 2020, NACE defines career readiness, identifies key competencies: at URL https://www.naceweb.org/career-readiness/ competencies/career-readiness-defined/, accessed June 3, 2020

Neidobf, S., 2008, Wanted-a first job in journalism-an exploration of factors that may influence initial

job-search outcomes for news-editorial students: Journalism \& Mass Communication Educator, v.

63, p. 56-65.

Pennycook, G., Ross, R., Koehler, D., and Fugelsang, J., 2017, Dunning-Kruger effects in reasoning-theoretical implications of the failure to recognize incompetence: Psychonomic Bulletin and Review, v. 24, p. 1,774-1,784.

Pierce, T., and Miller, T., 2007, Basic journalism skills remain important in hiring: Newspaper Research Journal, v. 28, p. 51-61.

Pitt, R., and Tepper, S., 2012, Double majors-influences, identities, \& impacts: The Curb Center for Art, Enterprise, \& Public Policy at Vanderbilt University, 95 p. https:// cdn.vanderbilt.edu/vu-wp0/wp-content/uploads/ sites/143/2019/03/28024246/Teagle_Report_Final_311-13.pdf, accessed February 21, 2021.

Purtha, R., Hillman, M., Kuban, A., Florea, F., and Gray, C., 2015, Ball State University students' local connection to Mississinewa watershed restoration project: Geological Society of America Abstracts with Programs, v. 47.

Reddington, R., 2011, Gender difference variables predicting expertise in lecture note-taking: New York, Columbia University, thesis, $76 \mathrm{p}$.

Reed, R., and Walker, G., 2002, Listening to scientists and journalists: Nieman Reports, v. 56, no. 3, p. 45-46.

Robertson, D. M., Schwarz, G. E., Saad, D. A., and Alexander, R. B., 2009, Incorporating uncertainty into the ranking of SPARROW Model nutrient yields from Mississippi/Atchafalaya river basin watersheds: Journal of the American Water Resources Association, v. 45, no. 2, p. 534-549.
Rosenfeld, S., and Ben-Hur, Y., 2001, Project-based learning in science and technology-a case study of professional development, in Science and technology education-preparing future citizens: Proceedings of the IOSTE Symposium in Southern Europe, Paralimni, Cyprus, April 29-May 2, 2001, 8 p.

Sanjek, R., 1990, A vocabulary for fieldnotes, in Sanjek, R., Fieldnotes-the makings of anthropology: Ithaca, N.Y., Cornell University Press.

Saydshoev, S., Borgmann, K., Kuban, A., and Florea, L., 2014, Reaching across the aisle:-combining media and science majors toward a common goal, in Communicating local water-quality data to the public-what they did \& how they did it: Midwest Ecology and Evolution Conference, Dayton, Ohio, March 1-2, 2014.

Shoemaker, C., 2010, Student confidence as a measure of learning in an undergraduate principles of horticultural science course: HortTechnology, v. 20, no. 4, p. 683-688.

Sprague, K., Haehnle, K., Phillips, E., Juranovitch, T., Florea, L., and Kuban, A., 2014, A water quality assessment of Buck Creek in east-central Indiana: Geological Society of America Abstracts with Programs, v. 46.

Sroufe, A., Allen, C., Kuban, A., and Florea, L., 2015, Promoting public awareness of water quality-showing how transdisciplinary students connected scientific data to the media: Geological Society of America Abstracts with Programs, v. 47.

Tseng, K., Chang, C., Lou, S., and Chen, W., 2013, Attitudes toward science, technology, engineering and mathematics (STEM) is a project-based learning environment: International Journal of Technology and Design Education, v. 23, no. 1, p. 87-102.

Twenge, J., 2013, Teaching Generation Me: Teaching of Psychology, v. 40, no. 1, p. 66-69.

Voelker, D., and Renn, D., 2000, Benthic invertebrates and quality of streambed sediments in the White River and selected tributaries: U.S. Geological Survey Water-Resources Investigations Report No. 99-4276.

Wilkie, D., 2019, Employers say students aren't learning soft skills in college: Society for Human

Resource Management, at URL https://www.shrm.org/ resourcesandtools/hr-topics/employee-relations/pages/ employers-say-students-arent-learning-soft-skills-in-college.aspx\, accessed June 3, 2020.

Yin, R., 2003, Case study research-design and methods: Thousand Oaks, Cal., Sage Publications, Inc. 
Appendix 1: Field Notebook Grading Rubric Water sample and calibration data managed on separate sheets

\section{General category}

Book title

Author name

Date range

Table of contents

2 points

2 points

2 points

4 points

\section{Field data - each page}

Name(s)

1 point

Date \& page number

1 point

Start Time

1 point

Location (GPS)

Weather conditions

1 point

1 point

Field site condition (slumped, well-exposed, wet, etc.)

1 point

Rock formations/soil types/water bodies present

1 point

Purpose of the site examination

Detail

Legibility

1 point

1 point

1 point

\section{Field sketch - each page}

Name(s)

Date \& page number

Start Time

Location (GPS)

Scale information

North arrow

Legend

Units

Detail

Legibility

Laboratory notes - each page

Name(s)

Date \& page number

Start Time

Lab Location

Sample information

Analysis method

Results /precision

Units and significant digits

Detail

Legibility

$\begin{array}{ll}\text { 1 point } & \\ \text { 1 point } & - \\ \text { 1 point } & \\ \text { 1 point } & \\ \text { 1 point } & - \\ \text { 1 point } & \\ \text { 1 point } & \\ \text { 1 point } & \\ \text { 1 point } & \\ \text { 1 point } & \end{array}$




\section{Class/group notes - each page}

Name(s)

Date \& page number

1 point

Start Time

1 point

Class/group work location

1 point

1 point

Topic

1 point

Purpose/activity

1 point

Accuracy

1 point

Proper citations/Referencing

1 point

Detail

Legibility

1 point

1 point

A) Total number of pages $x 10$

B) Total number of marks in each category $x 1$

C) Row $A-\operatorname{row} B$

Row C divided by row A x 200 (NOTEBOOK GRADE) 


\section{Appendix 1: Pretest posttest questionnaire on declarative concepts in water quality and multimedia}

\section{Science}

1) The National Environmental Policy Act of 1969 (NEPA) requires the preparation of an Environmental Impact Statement (EIS) for:

- Any projects that may significantly impact the environment

- $\quad$ All federal projects with budgets greater than one million dollars

- $\quad{ }^{* * * A l l}$ federal projects with the potential to significantly impact the environment

- Any construction project, public or private

2) An industrial site has a permit to release treated industrial waste into a local waterway. The effluent emerges from two large pipes. Such discharge would be called:

- $\quad$ Non-point-source pollution

- **Point-source pollution

- Neither, the discharge is not pollution

3) You have a sample of pure water at $20^{\circ} \mathrm{C}$ that is open such that is has equilibrated to the oxygen in the atmosphere. The sample of water warms to $30^{\circ} \mathrm{C}$ over the course of an hour. Assuming no other changes, what would happen to the amount of oxygen in the sample?

- It would increase

- $\quad$ **It would decrease

- It would stay the same

- $\quad$ None of the above answers are correct

4) A 'tile drain' in agricultural is?

- A ceramic-lined ditch that separates fields

- Vertical pipes scattered in a field designed to drain surface waters

- $\quad{ }^{* *}$ A subsurface, perforated pipe that helps to reduce soil saturation

5) The 'riparian zone' refers to:

- The steepest part of a river bank

- $\quad$ **The zone adjacent to a river with hydrophilic vegetation

- The entire floodplain surrounding a river

- All areas within a 100-year flood zone adjacent to a river

6) Sediments of silt or clay size are largely transported in a river by:

- **Suspension

- Saltation

- Bedload

- $\quad$ Dissolved load

7) The velocity of water in a straight segment of a stream is greatest

- In the center and at the bottom

- $\quad$ Near the banks

- It all moves the same speed

- $\quad * *$ In the center at $40 \%$ of the depth

8) Methods to reduce sediment and nutrient loss from an agricultural field include all of the following except:

- Contour or strip farming

- 'No till' farming

- Riparian buffers

- $\quad$ **Dainage tiles 
Media

1) Attribution in a news story provides which of the following?

- $\quad$ Names the source

- $\quad$ Allows the reader/viewer/listener to know who is responsible for the statement

- Helps the reader/viewer/listener evaluate the credibility of the statement

- $\quad{ }^{* *}$ All of the above

- $\quad$ None of the above

2) Which of the following questions would likely generate the best quotes or sound bites from an interviewee?

- Do you agree with the government's decision to raise taxes?

- $\quad$ **What happened when the robbery suspects entered the store?

- Does the governor's decision hurt his chances of winning re-election and why is the legislature opposed to his ideas?

- Didn't the director's action make you angry?

3) The Rule of Thirds requires that all photographers/videographers shoot two-thirds of their story with the subject fully centered in the frame.

- True

- **False

4) What is the minimum number of shots needed to make a sequence?

$-1$

- $\quad * * 3$

$-5$

- $\quad$ None of the above

5) Five pieces of information should be evident in all standard news stories. Which of the following best represents these elements?

- Commentary, rumors, who, what, number

- $\quad$ **Who, what, where, when, why

- $\quad$ Dramatization, when, where, why, how

- What, speculation, defamation, legality, number

- $\quad$ None of the above

6) When editing video, whenever possible, you should 'cut' the content where?

- $\quad$ **During movement

- After movement occurs

- When aesthetically appropriate

- $\quad$ None of the above

7) What do media practitioners call the audio that always exists at a scene?

- **Natural sound

- $\quad$ Reporter track

- $\quad$ Stereo sound

- $\quad$ Sound effects

- $\quad$ None of the above

8) In some instances, it is OK to publish/broadcast a story that contains inaccurate information, as long as some part of it is true.

- True

- **False 